\title{
Determining the Factors Affecting Liquidity Risk in Insurance Companies: Borsa İstanbul Example
}

\author{
İsmail YILDIRIM iD a \\ a Hitit University, Çorum, Turkey. ismailyildirim@hitit.edu.tr
}

\section{ARTICLE INFO \\ Keywords: \\ Risk \\ Liquidity Risk \\ Insurance \\ Insurance Business}

Received 3 September 2021

Revised 29 November 2021

Accepted 15 December 2021

Article Classification:

Research Article

\begin{abstract}
Purpose - Insurance companies face two types of risks when fulfilling their obligations. The first type of risks involves structure-specific risks available in insurance business. Among the insurance risks are death risk, longevity risk, natural disaster risk, premium risk, editing risk, etc. Such risks affect the performance and profitability of insurance companies. The second type of risks involves financial risks. Insurance companies seek to invest the premiums they collected in several investment instruments available for money and capital markets such as securities. Among these instruments are common stocks, debt instrument, exchange, etc. Insurance companies are subject to financial risks due to such instruments they hold. Stock risk, interest risk, exchange rate risk, liquidity risk, etc. are among the risks insurance companies are commonly exposed to. The purpose of this study is to identify the factors affecting the liquidity risk available in insurance companies.
\end{abstract}

Design/methodology/approach - Factors affecting the liquidity risk were intended to be identified using the main variables of liquidity for 5 insurance companies which are listed in Borsa Istanbul Stock Exchange (BIST) with a panel data regression analysis for a period between 2014 and 2020.

Results - The results of the analysis showed that the variables of loss ratio and return on equity are negatively correlated with the liquidity risk while variables such as company size and return on assets are positively correlated with the liquidity risk.

Discussion - The results of the study show the main indicators that insurance companies should pay attention to in order not to experience a liquidity-based risk. An insurance company that can manage its liquidity risk by taking these key factors into account will have an optimal size of liquidity and at the same time maximize its operating performance.

\section{INTRODUCTION}

Insurance companies are exposed to two types of risks in fulfilling their obligations. The first of these is the insurance risks specific to the insurance companies' own structures. Insurance risks include risks such as longevity risk, death risk, natural disaster risk, premium risk, and writing risk. Such risks affect the performance and profitability of insurance companies. A second type of risk that insurance companies may be exposed to is financial risks. Insurance companies want to invest the premiums they collect in various securities and instruments in the money and capital markets. These; stocks, debt securities, foreign currency, etc. may form. Insurance companies are exposed to financial risks due to these assets they own. Equity risk, interest rate risk, exchange rate risk, liquidity risk etc. Risks can be listed among the financial risks that insurance companies may be exposed to.

Risk is an element that needs attention in the insurance industry. Risk and insurance are often referred to together. Businesses and individuals resort to insurance to eliminate risk. Insurance companies transfer their insurance risks to institutions called reinsurance. Risk measurement and management is an extremely important element for insurance companies to fulfill their obligations (Drehmann and Nikolaou, 2013).

Businesses need cash due to their obligations. Therefore, they have to hold cash and cash equivalents. Liquidity indicates the ability of a business to meet its monetary obligations on time (Greenee, 2003). The liquidity level should be well adjusted. Having more cash than necessary and not using this cash in investments adversely affect the profitability of the business. On the contrary, it will negatively affect the reputation of businesses as it has insufficient cash and cannot fulfill its monetary obligations in the expected 
time. Therefore, businesses have to adjust the liquidity correctly. Businesses have to establish the right balance between liquidity, profitability and risk. Failure to achieve this balance leads to liquidity risk in businesses.

Liquidity risk is the risk of loss as a result of the inability of the insurance company to convert its assets into cash when it needs cash (Berger, 2006). In other words, the risk in question is defined as the risk that the insurance company will not be able to fulfill its obligation when requested. As it can be understood from the definition, although the insurance company has enough assets to pay its liabilities, these liabilities cannot be paid by the said bank because it cannot convert these assets into cash when needed. It is possible to talk about many reasons that cause insurance companies to be exposed to liquidity risk. The main reason behind the said problem is that the premiums collected by insurance companies are insufficient for claims payments.

Liquidity risk is one of the types of financial risks that insurance companies face, and it refers to whether insurance companies have the cash to meet their monetary obligations (Bonfim and Kim, 2012). What is essential in insurance companies is the coverage ratio of the premiums they collect from the insured to the damages that may occur. They must have sufficient cash to cover the damages that may occur during the insurance period.

Liquidity risk arises from the inability to find sufficient cash and cash equivalents or the inability to convert the assets that can be converted into cash, especially during periods of cash need (Gaspar and Sousa, 2010). Liquidity risk If the maturities of the assets owned by the enterprise are longer than the maturities of the operating liabilities, the liquidity risk increases even more. (CEIOPS, 2010). In particular, insurance companies are required to have enough cash to meet their obligations in claims payments. If an insurance company fails to calculate the increase in its liabilities well, the company that has liquidity problems may not be able to provide the liquidity it needs by converting its assets into cash in a short time.

This study was carried out to determine the liquidity risk, which causes insurance companies to fail to fulfill their obligations on time due to insurance activities. For this purpose, the factors affecting the liquidity risk of five insurance companies whose shares are traded in Borsa Istanbul were tried to be determined with the help of panel regression analysis.

\section{LITERATURE REVIEW}

There are no studies on liquidity risk management in the insurance sector, which are handled in different contexts. Studies in the literature on the measurement and management of liquidity risk are mostly in the banking sector. While some of the studies in the literature have analyzed the liquidity level of banks with different liquidity criteria, some have established a relationship between the liquidity status of banks and their performance.

Shen et al. (2010) used two alternative ratios as a measure of liquidity risk; the ratio of net loans to short-term loans and the financing gap ratio. It was determined that the results for both ratios were almost the same. Yıldırım (2011) created the market liquidity index that provides information on liquidity movement for Turkey and compared this indicator with the VIX index. Drehmann and Nikolau (2012) estimated the liquidity funding risk based on central bank auctions using the data of 877 European financial institutions in the 2005 2007 period. According to Brunnermeier (2012), the most important factor in the formation of liquidity risk is the bank liquidity mismatch.

Zengin and Yüksel (2016) investigated the factors affecting the liquidity risk of banks in Turkey with the logit model in the period of 2005-2014. The 10 banks with the highest asset size were included in the analysis and it was determined that the "capital adequacy ratio" and "net interest margin" variables affected the liquidity risk.

Çelik and Akrim (2012) tested the factors affecting the liquidity risk management of 9 banks traded in Borsa Istanbul between 1998 - 2008 using panel regression analysis.

\section{DATA AND METHOD}

Factors affecting the liquidity risk of insurance companies were determined by the Panel Data Regression analysis method. Panel data are defined as time series of sections (Greene, 2003). Before performing panel data regression analysis, the first thing to do is to determine the existence of the relationship between the variables 
(Çelik and Akrim, 2012). Three different panel unit root tests were used to test the existence of spurious relationships between the variables. In time series analysis, unit root tests are a frequently preferred method by researchers (Baltagi, 2001: 1). Unit root tests are used extensively in panel data regression analysis.

The existence of the relationship between the variables was tried to be determined by Levin, Chu and lin tests. With the help of Im, Pesaran and Shin tests, unit root calculations were made for each cross-section. The test of the stationarity of the series was tried to be determined by the Generalized Dickey Fuller test. When the results of each applied test were examined, the result was "there is a unit root process in the series".

The insurance companies included in the analysis are given in Table 1.

Table 1. Insurance Companies Covered by the Analysis

\begin{tabular}{ll}
\hline Code & Company Name \\
\hline AKGRT & Ak Insurance \\
\hline ANSGR & Anadolu Insurance \\
\hline ANHYT & Anadolu Hayat Pension \\
\hline GUSGR & Güneş Insurance \\
\hline RAYSG & Ray Insurance
\end{tabular}

The data used in the study were obtained from the period-end financial statements of insurance companies whose shares are traded in Borsa Istanbul (BIST). Five insurance companies whose year-end financial statements were published between the years 2014-2020 of the insurance companies traded in Borsa Istanbul were included in the analysis. Within the scope of the analysis, quarterly financial statements of insurance companies were used and financial statements of insurance companies were obtained from the Public Disclosure Platform (KAP).

The financial variables used in the analysis are given in Table 2 .

Table 2. Variables Included in the Analysis

\begin{tabular}{cl}
\hline \multicolumn{1}{c}{ Variable } & \multicolumn{1}{c}{ explanation } \\
\hline Liquidity Risk (LR) & $\begin{array}{l}\text { It is the ratio of financing deficit to total assets and also represents the } \\
\text { liquidity risk. Financing gap is the difference between the premiums } \\
\text { collected and the total loss amount. } \\
\text { The company size was calculated by taking the natural logarithms of } \\
\text { the total assets of the insurance companies. }\end{array}$ \\
$\begin{array}{c}\text { Risky liquid assets consist of premium totals and securities. It } \\
\text { represents the ratio of total assets. }\end{array}$ \\
Risky Liquid Assets (RLV) \\
It is the ratio of liquid assets considered less risky to total assets. Low- \\
risk liquid assets consist of government debt securities and cash and \\
cash equivalents. \\
[Paid Claims + Outstanding Claims Provisions - Transferred \\
Outstanding Claims Provision] / [Paid Current Risk Provision + \\
Current Year Premiums - Current Risk Provision] \\
It is calculated by dividing the net profit after tax at the end of the \\
period to the equity.
\end{tabular}

Among the variables included in the analysis, Liquidity Risk (LR) constitutes the dependent variable. Liquidity risk, which is the dependent variable, represents the ratio of the difference between total premiums and total loss amount to total assets. One of the most important risks in insurance companies is that the collected premiums are insufficient to cover the damages. 
Size (B), Risky Liquid Assets (RLV), Damage Premium Ratio (HPO), Return on Equity (RO), Low Risk Liquid Assets (ARLV) are included in the analysis as independent variables. Total assets of insurance companies were taken as the size variable. They were included in the analysis by taking the natural logarithms of their total assets. Risky liquid assets variable consists of total premium and securities and represents its ratio to total assets. Low-risk liquid assets represent the ratio of government debt securities and cash and cash equivalents to total assets. The loss premium ratio represents the ratio of the sum of paid claims and outstanding claims (provision for claims that have occurred but not yet paid) to the sum of premiums collected and current risk provisions. The return on equity variable is calculated by dividing the net profit to the equity.

\section{FINDINGS AND DISCUSSION}

After the unit root tests, summary statistics of the variables and their averages by years are presented in Table 3 and Table 4.

Table 3. Summary Statistics

\begin{tabular}{lcccccc}
\hline \hline & $L R$ & $B$ & $R L V$ & $A R L V$ & $H P 0$ & OKK \\
\hline Average & 20.248 & 2.1568 & 0,6987 & 0,2146 & 0,36587 & 0,14587 \\
Maximum & 68.154 & 1.2541 & 0,12547 & 0,12547 & 0,15487 & 6,24587 \\
Minimum & -1.254 & 5.8475 & 0,57845 & 0,13654 & $-1,21548$ & $-11,00215$ \\
S. Deviation & 0,1845 & 6.9874 & 1,36597 & 0,08887 & 0,26415 & 1,15484 \\
Distortion & $-0,2145$ & 1.4587 & 2,8745 & 0,51541 & $-1,15478$ & $-5,3254$ \\
Kurtosis & 3,1025 & 8.1254 & 12,47851 & 2,45874 & 8,1254 & 48,2458 \\
JB statistic & 2,0214 & $9,1254^{* * *}$ & $325,25487^{* * *}$ & 4,8736 & $169,1478^{* *}$ & $14447,26^{* * *}$ \\
\hline
\end{tabular}

The fact that the liquidity risk average is positive indicates that the premiums collected in the insurance sector are sufficient for claims payments. The positive value of the Damage Premium Ratio supports this result. It is desirable for insurance companies to have enough cash to meet their obligations. The skewness coefficient is 0 in the normal distribution. Negative skewness coefficient indicates right skewed distribution; positive skewness coefficient indicates left skewed distribution. The positive kurtosis coefficient indicates a pointed distribution, and the negative kurtosis coefficient indicates a flattened distribution. The kurtosis coefficient is also 0 in the normal distribution. The positive kurtosis coefficient indicates a pointed distribution, and the negative kurtosis coefficient indicates a flattened distribution. These values are expected to remain in the range of $(-1,+1)$ so that the distribution does not differ significantly from the normal distribution.

Table 4 shows the averages of the variables over the years.

Table 4. Averages of Variables by Years

\begin{tabular}{rrrrrrr}
\hline & $L R$ & $B$ & $R L V$ & \multicolumn{1}{c}{$A R L V$} & \multicolumn{1}{l}{$H P O$} & \multicolumn{1}{c}{ Ö } \\
\hline 2014 & 2,8553 & 2,2270 & 2,8852 & 2,9070 & 0,5223 & 5,0205 \\
2015 & 2,2529 & 2,5299 & 2,2222 & 2,2773 & 0,5778 & 5,5287 \\
2016 & $-2,9022$ & 0,5202 & 2,2805 & 2,3595 & $-0,2227$ & 2,5225 \\
2017 & $-3,7885$ & 0,8029 & 2,2772 & 2,2830 & $-0,2838$ & $-25,2220$ \\
2018 & 2,7328 & 0,8088 & 2,0333 & 2,2722 & 0,7223 & 2,2399 \\
2019 & 2,7770 & 0,8507 & 2,2282 & 2,5853 & 0,8228 & 2,2525 \\
2020 & 0,3709 & 0,0902 & 2,2250 & 2,8889 & 0,5220 & 2,2092 \\
\hline
\end{tabular}

The variables used in this study were taken at 3 months. Only the averages of the variables by years are included in the table. When the values of the variables in Table 4 are analyzed by years, it is seen that the liquidity risk values are mostly positive. Only the averages for 2016 and 2017 are negative. Premium production increased in 2016, but more claim payments also increased.

In panel data analysis, as in all-time series analyses, variables must be stationary in order to avoid spurious relationships between variables by performing both time and cross section analyzes at the same time. In this study, common unit root processes were investigated with the Levin, Lin and Chu panel unit root tests. At the 
same time, unit root processes were tested for each unit with the help of Im, Pesaran and Shin tests. With the help of the Generalized Dickey Fuller (ADF) test, the stationarity of the unit-free series was investigated.

In the Levin, Lin and Chu panel unit root tests, the existence of a common unit root is tested with hypotheses. The existence of an individual unit root is tested in the Im, Pesaran and Shin test. With the help of the generalized Dickey Fuller test, the presence of panel unit root was determined in the series. Table 5 shows the panel unit root test findings of the dependent and independent variables as a result of these analyses.

The ratio of the financing gap to total assets, which is one of the dependent variables we used in the analysis and represents the liquidity risk, was not stable at the level and at the 1st difference. It is stationary by taking the second difference of the variable. When the variables of external financing and risky liquid assets are taken as the 1st difference, these variables become stationary. These variables were included in the analysis with their 1st difference.

Table 5. Unit Root Test Results of Dependent and Independent Variables

\begin{tabular}{llll}
\hline & & \multicolumn{1}{c}{ Z statistic } & \multicolumn{1}{c}{ Decision } \\
\hline The dependent variable & Liquidity Risk (LR) & $-8.7125^{* * *}$ & Level Stable \\
\hline Independent variable & Size (B) & $-7.25812^{* * *}$ & Level Stable \\
\cline { 2 - 4 } & Risky liquid assets (RLV) & $-6,1461^{* * *}$ & Level Stable \\
\cline { 2 - 4 } & Low risk liquid assets (ARLV) & $-1,5870^{* *}$ & Level Stable \\
\cline { 2 - 4 } & Damage Premium Ratio (HPO) & $-5,6575^{* * *}$ & Level Stable \\
\cline { 2 - 4 } & Return on Equity (RO) & $-1,7947^{* *}$ & Level Stable \\
\hline
\end{tabular}

${ }^{*}, * *$ and ${ }^{* * *}$ indicate statistical significance at the $0.10,0.05,0.01$ level, respectively.

Before proceeding to panel data analysis, it is necessary to examine whether the process that creates the variables is stable over time, that is, whether the variables are stationary. Otherwise, if the estimates are estimated by the Least Squares method in the econometric model established between the non-stationary variables, unreal relationships can be obtained between the variables used after the shock to occur. This result is called spurious regression. In order to avoid this problem, a panel unit root test is performed to determine whether each variable is stationary or not. Non-stationary variables are excluded from the analysis, and the analysis is performed only with variables that are found to be stationary.

Return on equity and loss-premium ratio were found to be stable at the level and included in the analysis. Table 6 shows the findings obtained by panel data regression analysis.

Table 6. Panel Data Regression Results

\begin{tabular}{cc}
\hline The dependent variable & The Independent Variable (LR) \\
\hline C & $-0,0695$ \\
& $(0,2882)$ \\
& {$[-0,2413]$} \\
\hline B & 0,1908 \\
& $(0,2338)$ \\
& {$[0,8161]$} \\
\hline RLV & $-0,5649^{* *}$ \\
& $(0,2783)$ \\
& {$[-2,0293]$} \\
\hline ARLV & $1,0982^{* * *}$ \\
& $(0,3429)$ \\
& {$[3,2021]$}
\end{tabular}




\begin{tabular}{cc}
\hline HPO & $0,8530^{* *}$ \\
& $(0,4183)$ \\
& {$[2,0391]$} \\
\hline ÖK & $-0,0124^{* * *}$ \\
& $(0,0031)$ \\
& {$[-3,9371]$} \\
\hline R2 & 0,3849 \\
\hline F & $7,0902^{* * *}$ \\
\hline
\end{tabular}

In this study, which was carried out to determine the variables affecting the liquidity risk of insurance companies, it is seen that 4 of the 6 independent variables included in the model have a statistically significant relationship with the liquidity risk. These variables are risky liquid assets, loss ratio, return on equity, external financing.

The effect of the loss premium ratio on the liquidity risk of insurance companies was positive. As insurance companies' claim payments increase, the liquidity risk also increases. Since insurance companies have to provide a certain amount of coverage in return for the insurance policies they have issued and at the same time allocate a provision, it is important in terms of liquidity risk that they leave the premiums they have collected within their own structure.

The effect of external financing on the liquidity risk of insurance companies is positive and statistically significant. This situation shows that especially insurance companies' obtaining funds through external financing may further increase the effect on the liquidity risk of the company. If insurance companies use their own funds instead of external financing, this will reduce the liquidity risk downwards.

In the analysis applied to determine the factors affecting the liquidity risk of insurance companies, the return on equity variable has a negative effect on the liquidity risk. The increase in the return on equity of insurance companies will also reduce the need for foreign resources, thus reducing the liquidity risk.

The effect of risky liquid assets on the liquidity risk of insurance companies is negative. This result is inconsistent with the expectation that the increase in risky liquid assets will increase the liquidity risk of the enterprise to the same extent.

\section{CONCLUSION}

Businesses need cash while fulfilling their obligations as a result of their activities. Therefore, businesses keep cash and cash-like assets within the business in accordance with these obligations. Liquidity refers to the timely fulfillment of monetary obligations of a business. Companies need to be well-adjusted to keep cash within their organization. Having more cash than necessary is not preferred in inflationary environments. Having insufficient cash causes the problem of not fulfilling the obligations on time. Therefore, companies should determine their liquidity holding ratios accurately.

Liquidity risk relates to insurance companies not having enough assets to finance their obligations as they come due. It is important to determine whether an insurance company's cash flow is sufficient to meet its obligations on the policy and other receivables. Insurance companies operating under banks are affected by the liquidity risk in the banking sector based on their relations with banks. The contagion effect is seen for insurance companies that are part of banks.

In this study, which was conducted to determine the variables affecting the liquidity risk of insurance companies, it is seen that the loss premium rate and external financing variables have a positive effect on the liquidity risk, while the return on equity and risky liquid assets variables have a negative effect on the liquidity risk. The results of the study show the main indicators that insurance companies should pay attention to in order not to experience a liquidity-based risk. An insurance company that can manage its liquidity risk by taking these key factors into account will have an optimal size of liquidity and at the same time maximize its operating performance.

- There is a positive and significant relationship between the risky liquid assets variable and the liquidity risk of the insurance company at the $5 \%$ significance level. 
- There is a positive and significant relationship at the $5 \%$ significance level on the liquidity risk of the loss premium ratio variable. As insurance companies' claim payments increase, the liquidity risk also increases.

- There is a positive and significant relationship between return on equity and liquidity risk at the $5 \%$ significance level.

- There is a positive and significant relationship between the external financing variable and the liquidity risk. This situation shows that especially insurance companies' obtaining funds through external financing can further increase the effect on the liquidity risk of the company.

- The effect on insurance company size and liquidity risk is positive, but this positive effect is not statistically significant at any significance level.

The factors that are effective in the liquidity risk management of insurance companies operating in the Borsa Istanbul Insurance sector in the period covering the years 2014-2020 were investigated by taking into account bank-specific variables. In future studies, the effect of ownership in terms of liquidity can be examined by taking into account the ownership structure of banks. In addition, the effects of the global financial crisis on liquidity risk can be analyzed by separating the data set into pre-crisis and post-crisis periods. Finally, since there is no consensus in the literature on how to measure liquidity risk, the analysis can be repeated using different liquidity risk measures in future studies and the results can be compared.

\section{RESOURCES}

Baltagi, B. (2001). Econometric Analysis of Panel Data, 2nd Ed., UK: John Wiley \& Sons Ltd.

Berger, A. N., Bowman, C. H. S. (2006). The measurement of bank liquidity creation and the effect of capital. US Federal Reserve System. Available at: http://fic.wharton.upenn.edu/fic/papers/07/0702

Bonfim, D., Kim, M. (2012). Liquidity Risk in Banking: Is There Herding. European Banking Center Discussion Paper No. 2012-024. https://doi.org/10.2139/ssrn.2163547

Brunnermeier M. K., Krishnamurthy A., Gorton G. B. (2012). Liquidity Mismatch Measurement in Systemic Risk and Macro Modeling, NBER.

CEIOPS (2010). Committee of European Insurance and Occupational Pensions Supervisors. 2010. “Task force report on the liquidity premium", Working Document, CEIOPS-SEC-34/10.

Çelik, S., Akarım, Y., Akarım, D. (2012). Likidite Riski Yönetimi: Panel Veri Analizi ile İMKB Bankacılık Sektörü Üzerine Ampirik Bir Uygulama. Eskişehir Osmangazi Üniversitesi Sosyal Bilimler Dergisi, 13(1), 1-17.

Çelik, S., Akarım, Y.D. (2012). Likidite Riski Yönetimi: Panel Veri Analizi ile İMKB Bankacılık Sektörü Üzerine Ampirik Bir Uygulama, Eskişehir Osmangazi Üniversitesi Sosyal Bilimler Dergisi, 13(1), 1-17.

Drehmann M., Nikolaou K. (2012). Funding liquidity risk: definition and measurement. European Central Bank.

Drehmann, M., Nikolaou, K. (2013). Funding Liquidity Risk: Definition and Measurement, Journal of Banking \& Finance, 37(7), ss. 2173-2182.

Gaspar, M.R., Sousa, H. (2010). Liquidity risk and Solvency II, Insurance Markets and Companies: Analyses and Actuarial Computations, Volume 1, Issue 3

Greenee, W. H. (2003). Econometric Analysis, 5th Ed., New York: Prentice Hall.

Shen C. H., Chen Y. K. Kao L. F., Yeh C. Y. (2010). Bank Liquidity Risk and Performance. International Monetary Fund Working Paper.

Yıldırım, B.D. (2011). Finansal Piyasa Likiditesi, Ölçümü ve Analizi Central Bank Review, 11, 11-28.

Zengin, S., Yüksel, S. (2016). Likidite Riskini Etkileyen Faktörler: Türk Bankacıllk Sektörü Üzerine Bir İnceleme., İstanbul Ticaret Üniversitesi Sosyal Bilimler Dergisi, 29, 77-95 